\title{
An Effort to Improve the Playing Skill Through the Application of Tool Modification in Small Ball Game
}

\author{
(A Classroom Action Research)
}

\author{
Lukmannul Haqim Lubay*, Andari Dewi Purnama \\ Faculty of Sport and Health Education \\ Universitas Pendidikan Indoensai \\ Bandung Indonesia \\ *liebelubay@yahoo.com
}

\begin{abstract}
This research is motivated by the low aspect of skill of students in kasti ball game. The tool used is difficult because it does not match the characteristics of students an Elementary School in Majalengka Regency. The purpose of this study was to improve the playing skills in small ball game learning. The method used in this research was the classroom action research (PTK), while the instrument used was the Games Performance Assessment Instrument (GPAI). The subjects of the research were 20 fifth grade students, consisting of 10 male students and 10 female students. This research was conducted at an Elementary School in Majalengka Regency. Research data were taken by using observation sheets of play skill assessments, field notes, and research documentation. The results of this study showed that the application of modification tools in small ball game learning could provide positive benefits to the learning process for students, showed by the increase from cycle I to cycle II. Based on data processing and analysis, it showed that the application of tool modification could improve students' playing skills in small ball game learning. It can be concluded that the results showed the improvement of each action and showed that the application of the modification of learning tools could improve the playing skills of the fifth grade students of an Elementary School in Majalengka Regency.
\end{abstract}

Keywords: physical education, learning modification, small ball game

\section{INTRODUCTION}

Education is a very important factor for humans, because basically humans are born without carrying anything except the basis that needs to be developed to progress even humans are required to carry out education both formally, informally, and informally. Thus humans in carrying out the functions of life cannot be separated and will never be separated from education, because education serves to improve the quality of human beings both individuals and groups, both physical, spiritual, spiritual, material and thinking maturity, in other words to improve the quality of sources human power.

In the learning process in schools, the basic problem that must be done by the teacher is how a teacher can deliver interesting subject matter so that students are able to understand appropriately and obtain maximum results. Likewise in ongoing learning activities, students can have an understanding and skills about the subject matter taught in learning activities. This implies that the success of learning in achieving educational goals is highly dependent on the process of teacher and student learning activities, therefore teachers as learning agents are also required to be able to deal with learning difficulties experienced by students themselves. In addition, teachers are also required to recognize and understand the condition of the subject of learning both internally and externally. Education is a conscious and planned effort to create an atmosphere of learning and learning process so that students actively develop their potential to have spiritual spiritual strength, self-control, personality, intelligence, noble character, and the skills needed by themselves, society and the country [1].

Based on the explanation, education is a process that is carried out consciously and plans in an effort to create a conducive learning process that encourages students to develop their abilities and potential. Physical education in elementary schools is one of the facilities that facilitates physical, mental development and training in motion processing so that children can move well and can improve children's social abilities for the better. Physical education is essentially an educational process that utilizes physical activity to produce holistic changes in individual quality, both in physical, mental, and emotional terms [2].

Physical education is part of the general education process, which aims to develop the physical, mental, emotional and social well-being of children, with physical activities as a source [3]. As formulated as a National reference in Lutan and Sumardianto states that "The function of physical education to contribute to overall education: Physical education is an integral part of education through physical activities aimed at improving individuals organically, neuromuscularly, intellectually and emotionally" [4].

Based on the above opinion that the goal of physical education learning is a physical education learning process that focuses on student activities that can improve the physical and physical abilities of students to be better. And besides, it can improve students' movement skills in carrying out physical education learning activities, and can build sportsmanship, 
physical education learning in SDN Burujul Kulon 1 Majalengka City, based on observations, a problem occurred, namely the role of the teacher at the school when giving material seemed boring to students. Why is that, because the teacher only instructs students to do the learning, without paying attention and giving direction to students about what will be taught. Therefore students can only do learning activities without knowing what learning is contained in baseball games. Besides that, the learning tools given by the teacher to students in learning baseball games are not appropriate given to students. Therefore students become less skilled and tend to feel difficulty in carrying out baseball activities. From various skills found in baseball games such as throwing, catching, hitting and running. The facts that occur in the field are lack of playing skills in baseball games. Therefore, researchers try to modify the learning tool. It is expected that by modifying the bat in the baseball game, students' skills in playing in baseball game activities can be improved. And besides can improve baseball skills playing baseball, modifying learning tools are expected to reduce the level of difficulty experienced by students in doing baseball games.

\section{METHOD}

The method used in research is Classroom Action Research is a practical research that is intended to improve classroom learning. This research is one of the efforts of the teacher or practitioner in the form of various activities carried out to improve and or improve the quality of learning in the classroom.

\section{A. Research Subject}

The research subjects in this CAR were students in grade $\mathrm{V}$ of SDN Burujul Kulon 1, Majalengka City, totaling 20 students with 10 male students and 10 female students. Students at this school come from different family backgrounds, their parents come from different professions, some are professionals as traders, employees, teachers, and others.

\section{B. Research Procedure}

In relation to this class action research refers to Kurt Lewin's class action research model namely "PTK procedure refers to the design of the study which is designed in stages, namely the stage of determining the action plan, implementing the action, observing, analyzing and analyzing reflection" [6].

\section{Instrument}

The instrument or tool used to collect data in this study is the Game Performance Assessment Instrument (GPAI) used to measure or assess the student's playing ability. Playing skills in question have 3 constructs, namely (1) Decisions taken, (2) Implementing skills, (3) Providing support.

\section{RESULTS AND DISCUSSION}

\section{A. Results}

The following is the data of the results of the analysis of actions through 2 cycles carried out in the implementation of classroom action research in the Application of the Teams
The curriculum used at SDN Burujul Kulon 1 Majalengka City is the Education Unit Level Curriculum (KTSP). In 
improve, and encourage changes in abilities that the student has. Giving and presenting the challenges of carrying out the task of motion should be in the form of games so that children feel happy and enthusiastic in participating in learning. According to Hanief "Through play activities, it is very appropriate to develop basic movement skills of children in primary school, because basically the world of children is the world of play" [7]. Based on the explanation, it can be concluded that by playing, the basic mobility abilities possessed in children will be well developed. Because basically every day a child will not be separated from an activity or activities he does is play.

\section{CONCLUSION}

The results of research conducted by researchers from initial observations to Cycle II that have been described in the previous discussion, the researchers concluded that through the application of tool modifications can improve student playing skills in baseball games in class V SDN Burujul Kulon 1 Majalengka City, based on analytical processing the data of catching and hitting skills has increased. This can be seen from the number of students who have exceeded the KKM achieved by each action.

\section{REFERENCES}

citing. Then when giving learning to students the teacher is not structured systematically so that many students do not want to follow the learning by reason of the motion assignment in learning baseball games that will be learned too difficult.

From the results of the implementation of the class action obtained facts, namely the presentation of learning through the application of modified tools in learning baseball games with games by the teacher can improve the skills of throwing, catching, and hitting the ball. As stated by Arda and Darmawan "Modification is one of the efforts that can be done by teachers so that the learning process can run well. Besides that can increase student learning activities in accordance with the objectives ". The results showed that through the application of the modification of the bat and ball can improve student learning outcomes of the baseball hit from pre-action to cycle I and cycle I to cycle II Pawestri. Based on the explanation, it can be concluded that the modification can be said as a form of effort made by a teacher to provide different learning, by paying attention to the students' ability to understand and do what has been conveyed by the teacher, so that students can understand and do their assignments well and can improve,
[1] Undang-Undang Republik Indonesia. (2003). Undang-undang Republik Indonesia Nomor 20 Tahun 2003 Tentang Sistem Pendidikan. Jakarta:

[2] Mahendra, A. (2009). Asas dan Falsafah Pendidikan Jasmani. Program Studi Pendidikan Jasmani Kesehatan dan Rekreasi. Bandung: UPI.

[3] Sukintaka. (1992). Teori Bermain. Bandung: Departemen Pendidikan Dan Kebudayaan Direktorat Jenderal Pendidikan Tinggi Proyek Pembinaan Tenaga Pendidikan. Pendidikan Dan Kebudayaan Direktorat Jenderal Pendidikan Dasar Dan Menengah.

[5] Bahagia, Y. Mujianto, S. (2009). Media dan Alat Pembelajaran Penjas. Jurusan Pendidikan Olahraga Fakultas Pendidikan Olahraga dan Kesehatan Universitas Pendidikan Indonesia.

[6] Subroto, T. dkk. (2016). Penulisan Penelitian Tindakan Kelas Dalam Pendidikan Jasmani, Olahraga, Dan Kesehatan. Bandung: Universitas Pendidikan Indonesia.

[7] Hanief, N. Y. (2015). Membentuk Gerak Dasar Pada Siswa Sekolah Dasar Melalui Permainan Tradisional. Jurnal: Sportif. 1 (1). SISDIKNAS

[4] Lutan, R. Sumardianto. (2000). Filsafat Olahraga. Departemen 